\title{
SARS-CoV-2-IgG Response and the Role of ACE2 G8790A and ACE I/D Polymorphic Variants as Determinants of Covid-19 Severity-A Genetic Association Study in north Indian Population
}

\section{Gawharul Haq Malik}

Sher-i-Kashmir Institute of Medical Sciences

Imtiyaz A Bhat

Sher-i-Kashmir Institute of Medical Sciences

\section{Sadaf Rasool}

Sher-i-Kashmir Institute of Medical Sciences

Insha Bashir

Sher-i-Kashmir Institute of Medical Sciences

\section{Arooja Bashir}

University of Kashmir

\section{Taief A Dar}

Sher-i-Kashmir Institute of Medical Sciences

tabassum Shafi

Sher-i-Kashmir Institute of Medical Sciences

\section{Fouzia Rashid}

University of Kashmir

\section{Shariq R Masoodi}

Sher-i-Kashmir Institute of Medical Sciences

Zafar A Shah ( $\nabla$ gowharimmuno@gmail.com )

Sher-i-Kashmir Institute of Medical Sciences https://orcid.org/0000-0003-0136-6058

\section{Research Article}

Keywords: Anti-SARS-CoV-2 IgG response, Chemiluminescence, ACE Polymorphism, Covid-19 risk stratification, predictive biomarkers

Posted Date: August 23rd, 2021

DOl: https://doi.org/10.21203/rs.3.rs-764798/v1 
License: (c) (i) This work is licensed under a Creative Commons Attribution 4.0 International License. Read Full License 


\section{Abstract}

Background: Angiotensin-converting enzyme-ll and Angiotensin-converting enzyme are an integral part of Renin-Angiotensin system and mediate SARS-CoV-2 infection and outcome. Here we studied the role of host antibody response to SARS-CoV-2, ACE2 G8790A single nucleotide polymorphism, and ACE insertion/deletion (ACE I/D) as key determinants of Covid-19 severity and outcome.

Methods: We evaluated anti-SARS-CoV-2 IgG titers by chemiluminescence. ACE2 G8790A and ACE I/D were analyzed by polymerase chain reaction-restriction fragment length polymorphism method (PCRRFLP) and PCR respectively.

Results: The overall positivity rate for SARS-CoV-2-IgG was $83.72 \%$, but a significantly lower positivity was observed in asymptomatic subjects $(66.67 \%, p<0.05)$. Anti-SARS-CoV-2 IgG levels were comparatively higher in subjects who required hospitalization (13.06 \pm 14.42 vs $7.37 \pm 10.79, p<0.05)$. ACE2 G8790A 'AA' genotype was significantly higher in subjects who did not require hospitalization (OR=0.40, $\mathrm{Cl} 0.14-0.71, \mathrm{P}=0.007$ ). In addition, the frequency of ACE I/D 'ID' genotype was significantly lower in symptomatic as compared to asymptomatic subjects $(\mathrm{OR}=0.235, \mathrm{Cl} 0.09-0.56, \mathrm{P}=0.001)$.

Conclusion: In summary, the current study shows that serological response to SARS-CoV-2 is more pronounced in symptomatic and severe covid-19 cases. Both ACE2 G8790A 'AA' and ACE I/D 'ID' genotype were observed to show protective role as far as the severity of covid-19 infection was considered. The study provides preliminary evidence of a genetic link between the analyzed polymorphic variants and covid-19 severity suggesting a subtle way of covid-19 risk stratification and utilization of respective variants as predictive biomarkers.

\section{Introduction}

Severe acute respiratory syndrome (SARS) caused by Novel coronavirus (CoV) generally recognized as 'COVID-19' by the World Health Organization (WHO) broke out at the beginning of December 2019 in Wuhan City, Hubei Province, China [1]. This strain most often affects the respiratory system of humans besides the gastrointestinal system [2, 3]. Most infected individuals experience mild to moderate symptoms usually after less than a week of infection, such as high body temperature in addition to respiratory symptoms such as cough, sore throat, nasal congestion, fatigue, and headache. Some people preferentially with underlying co-morbidities may develop severe symptoms like pneumonia or acute respiratory distress syndrome as observed on computed tomography [4-6]. Prominent signs of pneumonia include decreased oxygen saturation, blood gas deviations, changes visible through chest Xrays including ground glass abnormalities, patchy consolidation, and alveolar exudates indicating tissue deterioration [7]. Lymphopenia appears to be common and inflammatory markers like C-reactive protein (CRP), D-dimers, ferritin, lactate dehydrogenase (LDH), and IL-6 are most often elevated [8, 9]. SARS is a highly contagious menace and is supposed to spread rapidly via droplet particles. The droplet particles containing SARS-CoV-2 may arise through sneezing or coughing which may infect healthy individuals in 
close contact with the patient [10-13]. Because of rapid outspread, the World Health Organization (WHO) declared it a Public Health Emergency of International concern on 30th January 2020, followed by declaring it as a Global Pandemic on 11th March 2020, nearly 3 months after its first appearance. According to the latest updates of WHO, this disease has affected 223 countries or territories and currently, the number of cases reported globally exceeds 180 million with almost 4 million worldwide deaths [14].

The pathological mechanisms involved in the interaction of SARS-CoV-2 are of key significance for infection and viral replication. The interaction of SARS-CoV-2 with the host cells is mediated by ACE 2 receptor present on epithelial cells of the respiratory tract, most of the organs of the gastrointestinal tract, lymph nodes, arterial and venous endothelial cells, and arterial smooth muscle cells [15]. This interaction has already been expounded in detail suggesting ACE 2 to be the key determinant of SARS-CoV-2 infection. Various studies have reported significant differences in the frequency of ACE 2 variant (rs2285666/G8790A) in covid-19 infected sub-populations. This variant has been reported to have a mean frequency of 0.6 in Indian population as compared to 0.2 in Europeans and 0.55 in East Asians. Srivastawa et al 2020 revealed a significantly higher $(P<0.0001)$ frequency of this variant among Indian populations in comparison to European or Afro-American populations [16]. G8790A polymorphism has already been reported to carry a potential risk for hypertension, coronary artery diseases, and type II diabetes which translates its possible role as a predisposing factor associated with covid-19 related comorbidities. This variant is located at the beginning of intron 2, thereby may play a possible role in the splicing process which may inturn alter the expression level of ACE 2. Asselta et al 2020 reported G8790A ' $A$ ' allele to increase the expression of ACE 2 protein [17]. A study carried out in the Indian sub-continent showed a strong correlation of G8790A 'AA' genotype with the lower infection rate and lower case fatality rate (CFR) [16]. ACE 2 is a component of RAAS and works in coordination with angiotensin I converting enzyme (ACE) which converts angiotensin I to angiotensin II, a potent vasoactive peptide. Besides G8790A polymorphism, an important Insertion Deletion polymorphism (rs4646994) of the ACE gene bears potential implication in covid-19 [18]. ACE gene is located on chromosome 17q23.3 and rs4646994 involves the presence or absence of a 287 base pair sequence in intron-16 of the gene. Various evidence suggest that $D$ allele or $D D$ genotype could elevate blood pressure, risk of CVD, atherosclerosis, diabetic nephropathy and coronary heart disease [19]. ACE ID and G8790A polymorphisms are probably in linkage disequilibrium and DD/GG combination of these polymorphisms have been reported to confer a significative increased risk of developing hypertension [20]. A meta-analysis conducted by Y.li et al reported a significant association between the ACE ID "D" allele in Chinese population. The relation between ACE ID polymorphism and various disease states is conflicting, as many studies have failed to associate these variants with co-morbidities like coronary artery diseases, hypertension and diabetes [21-23].

The synergistic role of ACE2 and ACE cannot be neglected in covid-19 pandemic as these are the important components of the host reception platform for SARS-CoV-2 virus [24]. Because of the fact that the above mentioned co-morbidities play crucial role in deciding the fate of covid-19 infection coupled 
with a remarkable role of ACE and ACE2 in these disease states, we assessed the role of ACEI/D and G8790A ACE2 polymorphisms as risk factors for severity of covid-19 infection [25].

\section{Methodology}

\subsection{Subject selection and recruitment}

The current study was conducted in the Department of Immunology and Molecular Medicine, in collaboration with the department of General Medicine, Sher-i- Kashmir Institute of Medical sciences, Srinagar (SKIMS), between December 2020 and June 2021. The ethical approval was granted by the institutional ethics committee vide approval number 14/2020. A total of 127 post covid-19 RT confirmed negative subjects who visited the department to check their IgG levels for plasma donation were recruited. The participants were verbally informed about the nature of the study and its possible outcome and a written consent was taken as directed by the ethical committee of the institute. A detailed questionnaire was completed for each patient that included information on age, gender, blood group, dwelling, occupation, smoking, source of infection, symptoms besides other clinical parameters as depicted in Table 1. 
Table 1

Comparison of anti-SARS-CoV-2 IgG levels with different clinicopathological and demographic features

\begin{tabular}{|lll|}
\hline Parameter $(\mathbf{n}=127)$ & IgG $($ Mean \pm SD) & P-value \\
\hline Symptoms & $7.41 \pm 7.83$ & 0.17 \\
Present (69.3\%) & $10.50 \pm 14.53$ & \\
Absent (30.7\%) & & \\
\hline Underlying Disease & $12.82 \pm 18.82$ & 0.29 \\
Present (10.23\%) & $8.88 \pm 11.51$ & \\
Absent (89.76\%) & & \\
\hline Smoking history & $1.54 \pm 2.36$ & 0.01 \\
Present (10.23\%) & $9.89 \pm 12.64$ & \\
Absent (89.77\%) & & \\
\hline Dwelling & $12.16 \pm 15.62$ & 0.01 \\
Urban (48.03\%) & $6.50 \pm 7.49$ & \\
Rural (51.96\%) & & \\
\hline Occupation & & \\
Health worker (40.94\%) & $10.50 \pm 14.53$ & \\
Non health worker (59.05\%) & & \\
\hline Hospitalization Required & $13.06 \pm 14.42$ & 0.0 .01 \\
Yes (33.07\%) & $7.37 \pm 10.79$ & \\
\hline No (66.92\%) & & \\
\hline H1N1 Vaccination Done & $8.94 \pm 9.78$ & \\
Yes (29.92\%) & $9.48 \pm 14.44$ & \\
No (70.07\%) & & \\
\hline Age & & \\
\hline$<35$ Years (57.48\%) & & \\
$\geq 35$ Years (42.52) & & \\
\hline Blood Group & & \\
\hline O + ive (29.92\%) & & \\
\hline O-ive (4.72\%) & & \\
\hline
\end{tabular}




\begin{tabular}{|lll|}
\hline Parameter $(\mathbf{n}=127)$ & IgG $($ Mean \pm SD) & $P$-value \\
\hline A +ive $(17.32 \%)$ & $13.42 \pm 15.24$ & 0.208 \\
\hline A-ive $(1.57 \%)$ & $0.71 \pm 0.30$ & 0.345 \\
B +ive (31.49\%) & $9.68 \pm 13.35$ & 0.787 \\
B-ive (1.57\%) & $5.13 \pm 1.68$ & 0.662 \\
AB +ive (13.38\%) & $7.45 \pm 9.99$ & 0.665 \\
\hline
\end{tabular}

\subsection{Sample collection/storage}

$5 \mathrm{ml}$ of peripheral blood was collected from each study subject, which was aliquoted in serum and EDTA vials and stored at $-20^{\circ} \mathrm{C}$ until processing. Serum was used for estimation of IgG levels and whole blood was used for molecular analysis.

\subsection{Genotyping}

Genomic DNA was isolated from blood samples by phenol chloroform method/HiGenoMB, HIMEDIA DNA Miniprep Purification Kit (Cat.No. MB504). Prior to genotyping DNA quality and content was checked by Agarose gel electrophoresis and spectrophotometry respectively (Nanodrop Spectrophotometer, Eppendorf AG, Hamburg, Germany). Polymerase chain reaction (PCR) was performed using Thermal Cycler-Applied Biosystems, USA. ACE2 G8790A was genotyped using polymerase chain reactionrestriction fragment length polymorphism (PCR-RFLP) method. Amplification was carried out using specific primers with forward sequence 5'-CATGTGGTCAAAAGGATATCT - 3' and reverse sequence 5'AAAGTAAGGTTGGCAGACAT - 3'. Briefly, 20 $\mu$ reaction was carried out with 10x master buffer (TBG Biotechnology, corp), forward and reverse primers $(0.5 \mu \mathrm{mol} / \mathrm{I})$, Taq DNA polymerase $1.0 \mathrm{U}$ (KAPA Biosystems, Capetown) and DNA template (50-100ng). The reaction mixture was subjected to an initial denaturing step at $94^{\circ} \mathrm{C}$ for $5 \mathrm{~min}$. followed by 10 cycles; $94^{\circ} \mathrm{C}$ for $40 \mathrm{~s}, 65^{\circ} \mathrm{C}$ for $40 \mathrm{~s}$ and $72^{\circ} \mathrm{C}$ for $40 \mathrm{~s}: 15$ cycles; $94^{\circ} \mathrm{C}$ for $40 \mathrm{~s}, 65^{\circ} \mathrm{C}$ for 40 s and $72^{\circ} \mathrm{C}$ for $40 \mathrm{~s}$ : 20 cycles; $94^{\circ} \mathrm{C}$ for $40 \mathrm{~s}, 65^{\circ} \mathrm{C}$ for $40 \mathrm{~s}$ and $72^{\circ} \mathrm{C}$ and a final extension at $72^{\circ} \mathrm{C}$ for 20 minutes. The amplification products were digested overnight with Alu 1 (Fermentas, Life Sciences) and checked on $2.5 \%$ agarose gel which revealed RFLP pattern of GG 466bp; GA 466, $281 \mathrm{bp}, 185 \mathrm{bp}$ and AA $281 \mathrm{bp}, 185 \mathrm{bp}$. ACE I/D was directly analyzed on $2.5 \%$ agarose gel after amplification with forward primer 5'-CTGCAGACCACTCCCATCCTTTCT - 3' and reverse primer 5'GATGTGGCCATCACATTCGTCAGAT - 3'.

\subsection{Estimation of anti covid-19 IgG antibodies}

Anti covid-19 IgG kits were procured from Beckman Couter, USA and serological IgG levels were estimated by using chemiluminescence unicell DXI 800 .

\subsection{Statistical analysis}

Statistical analysis was performed using the software SPSS 23.0 (IMB SPSS Statistics 23) and Graph Pad Prism (Version 7.05, La Jolia, California, USA). Categorical variables were compared using Pearson's 
Chi square test/Fisher's exact test as appropriate. Continuous variables were compared using 'Student's unpaired t-test'; where the data was not normally distributed, an appropriate non-parametric test like Mann-Whitney U-test was used. Spearman correlation coefficient was used for correlation between the variables. All reported $P$ values were based on two-tailed tests. $P$-value of less than $0.05(<0.05)$ was considered statistically significant for all tests.

\section{Results}

\subsection{Study subjects}

Data from all the covid-19 patients was obtained from their personal interviews and clinical examinations which included their age, gender, blood group, dwelling, occupation, source of infection, covid-19 symptoms present or not, hospitalization required or not, history of vaccination, underlying diseases, and smoking (Table 1). Of the 127 covid-19 patients recruited, $97.63 \%$ were males and $2.36 \%$ were females, $48.03 \%$ were urban and $51.96 \%$ were rural. $40.94 \%$ of the patients were health workers and $59.05 \%$ were non health workers. Most of the patients (69.3\%) had symptoms at the time of diagnosis and hospitalization was required in $32.5 \% .10 .23 \%$ patients were smokers, and $89.77 \%$ were non smokers. H1 N1 vaccination was previously done in $29.92 \%$. The prevalent blood group in our set of patients was $B$ + ve (31.49\%), followed by O + ve (29.92\%), A + ve (17.32\%), AB + ve (13.38\%), O-ve (4.72\%), A-ve (1.57\%) and B-ve (1.57\%).

\subsection{Analysis of SARS-CoV-2 IgG levels vs clinicopathological and demographic features}

SARS-CoV-2 IgG levels were compared between different subgroups by running a bivariate analysis depicted in Table 1. A significant association was observed with smoking history, dwelling, hospitalization required and age. The mean (SD) of IgG levels in non smokers vs smokers was $9.89 \pm$ 12.64 vs $1.54 \pm 2.36$ ( $p=0.01)$ which was statistically significant. Urban dwellers had higher IgG levels ( $P$ $=0.01$ ) with a mean (SD) of $12.16 \pm 15.62$ as compared to $6.50 \pm 7.49$ in rural group. Patients aged above 35 had significantly higher IgG levels as compared to younger patients $(p=0.01)$. IgG levels were higher in covid-19 patients who required hospitalization as compared to those who did not require hospitalization $(p=0.01)$.

\subsection{Analysis of Resolution-time vs clinico pathological and demographic features}

Resolution-time of covid-19 infection for each patient was calculated as the time interval (No. of days) between the date of RT-PCR positive confirmation and date of covid-19 RT-PCR negative confirmation. The mean resolution-time for covid-19 infection in our study cohort was 12.53 with a standard deviation of 4.95. Resolution-time revealed a significant association with age and history of H1N1 vaccination, while as association with other parameters was statistically insignificant. Subjects aged above 35 years presented with a mean resolution-time of 13.76 days as compared to 11.78 days in the younger age 
group $(P=0.03)$. Patients who were previously vaccinated for $\mathrm{H} 1 \mathrm{~N} 1$ had a mean resolution-time of 11.13 \pm 3.34 in comparison to $13.24 \pm 5.47$ in patients who were not previously vaccinated $(p=0.03)$ (Table 2$)$. 
Table 2

Comparison of resolution-time with different clinicopathological and demographic features

\begin{tabular}{|c|c|c|}
\hline Parameter & $\begin{array}{l}\text { Resolution in days } \\
\text { (Mean } \pm \text { SD) }\end{array}$ & $P$-value \\
\hline $\begin{array}{l}\text { Age } \\
<35 \text { Years } \\
\geq 35 \text { Years }\end{array}$ & $\begin{array}{l}11.78 \pm 4.70 \\
13.76 \pm 5.23\end{array}$ & 0.03 \\
\hline $\begin{array}{l}\text { Symptoms } \\
\text { Present } \\
\text { Absent }\end{array}$ & $\begin{array}{l}12.63 \pm 15.19 \\
12.56 \pm 4.65\end{array}$ & 0.93 \\
\hline $\begin{array}{l}\text { Occupation } \\
\text { Health worker } \\
\text { Non health worker }\end{array}$ & $\begin{array}{r}12.46 \pm 4.43 \\
12.72 \pm 4.74\end{array}$ & 0.77 \\
\hline $\begin{array}{l}\text { H1N1 Vaccination Done } \\
\text { Yes } \\
\text { No }\end{array}$ & $\begin{array}{l}11.13 \pm 3.34 \\
13.24 \pm 5.47\end{array}$ & 0.03 \\
\hline $\begin{array}{l}\text { Underlying Disease } \\
\text { Present } \\
\text { Absent }\end{array}$ & $\begin{array}{l}11.53 \pm 3.15 \\
12.74 \pm 5.18\end{array}$ & 0.41 \\
\hline $\begin{array}{l}\text { Smoking history } \\
\text { Present } \\
\text { Absent }\end{array}$ & $\begin{array}{l}13.61 \pm 3.92 \\
12.54 \pm 5.18\end{array}$ & 0.47 \\
\hline $\begin{array}{l}\text { Hospitalization Required } \\
\text { Yes } \\
\text { No }\end{array}$ & $\begin{array}{l}12.17 \pm 5.93 \\
12.83 \pm 4.51\end{array}$ & 0.49 \\
\hline Blood Group & & \\
\hline $\mathrm{O}+\mathrm{ive}$ & $12.22 \pm 7.78$ & Reference \\
\hline O-ive & $15.83 \pm 7.78$ & 0.09 \\
\hline$A+i v e$ & $11.45 \pm 4.70$ & 0.51 \\
\hline A-ive & $13.00 \pm 9.89$ & 0.81 \\
\hline
\end{tabular}




\begin{tabular}{l|lll|}
\cline { 2 - 3 } & Parameter & $\begin{array}{l}\text { Resolution in days } \\
(\text { Mean } \pm \text { SD) }\end{array}$ & P-value \\
\hline B + ive & $12.97 \pm 5.38$ & 0.50 \\
\hline B-ive & $15.50 \pm 3.53$ & 0.28 \\
\hline AB + ive & $12.58 \pm 4.87$ & 0.77 \\
\hline 3.4. Correlation analysis between IgG levels, age and \\
resolution-time
\end{tabular}

Correlation analysis revealed a significant positive correlation between age \& IgG levels (Fig. 1). No significant correlation was observed between resolution-time and IgG levels (Fig. 2), and between Age and resolution time (Fig. 3).

\subsection{Genotyping of ACE2 G8790A and ACE I/D polymorphisms}

Regarding the genotypic frequencies, the results obtained for ACE2 G8790A polymorphism were $55.12 \%$ (GG), $0.78 \%$ (GA) and $44.09 \%$ (AA) (Table 3). Statistical analysis of G8790A revealed a significant association of this variant with severity of covid-19 infection (Table 4). AA genotype was observed to be protective as compared to $G G$ genotype $(O R 0.40(\mathrm{Cl}-0.141-0.717) P=0.007)$. Analysis of $G 8790 A$ on the basis of symptoms revealed no significant association (Table 4).

Table 3

Frequency analysis of ACE2 G8790A and ACE

ID Polymorphisms

\begin{tabular}{|lll|}
\hline Gene/ SNP & Frequency & Percentage \\
\hline ACE2 G8790A & & \\
\hline GG & 70 & $55.12 \%$ \\
\hline GA & 1 & $0.78 \%$ \\
AA & 56 & $44.09 \%$ \\
ACE ID & & \\
\hline DD & 23 & $18.1 \%$ \\
ID & 53 & $41.7 \%$ \\
II & 51 & $40.2 \%$ \\
\hline
\end{tabular}


Table 4

Analysis of ACE2 G8790A on the basis of severity and symptoms of covid-19 infection

G8790A Severity

\begin{tabular}{|c|c|c|c|c|c|c|}
\hline & $\begin{array}{l}\mathrm{HR}(\mathrm{n}= \\
41)\end{array}$ & $\begin{array}{l}\operatorname{HNR}(\mathrm{n}= \\
86)\end{array}$ & OR $(95 \% \mathrm{Cl})$ P-value & $\begin{array}{l}\text { Yes }(n= \\
83)\end{array}$ & $\begin{array}{l}\mathrm{No}(\mathrm{n}= \\
44)\end{array}$ & $\begin{array}{l}\text { OR }(95 \% \mathrm{Cl}) \mathrm{P}- \\
\text { value }\end{array}$ \\
\hline $\mathrm{GG}(70)$ & $30(70.27)$ & $40(48.89)$ & Reference & 50 & 20 & Reference \\
\hline $\mathrm{GA}(01)$ & 01 & 00 & - & 01 & 00 & - \\
\hline $\mathrm{AA}(56)$ & $10(29.73)$ & $46(51.11)$ & $\begin{array}{l}0.40(0.141-0.717) \\
0.007\end{array}$ & 32 & 24 & $\begin{array}{l}0.53(0.25-1.11) \\
0.13\end{array}$ \\
\hline
\end{tabular}

For ACE ID, the results obtained were 18.1\% (DD), 41.7\% (ID) and $40.2 \%$ (II) (Table 3). Analysis of ACE ID polymorphism on the basis of severity revealed no statistical significance. On the basis of symptoms, heterozygous (ID) genotype presented with an odds ratio of 0.37 which was statistically significant (OR = 0.37 (0.15-0.89), $\mathbf{P}=\mathbf{0 . 0 3 2}$ ) (Table 5).

Table 5

Analysis of ACE I/D on the basis of severity and symptoms of covid-19 infection

\begin{tabular}{|c|c|c|c|c|c|c|}
\hline ACE & Severity & & & Symptor & & \\
\hline$\|(51)$ & $\begin{array}{l}\mathrm{HR}(\mathrm{n}= \\
41)\end{array}$ & $\begin{array}{l}\operatorname{HNR}(\mathrm{n}= \\
86)\end{array}$ & $\begin{array}{l}\text { OR }(95 \% \mathrm{Cl}) \mathrm{P}- \\
\text { value }\end{array}$ & $\begin{array}{l}\text { Yes }(n= \\
83)\end{array}$ & $\begin{array}{l}\text { No }(n= \\
44)\end{array}$ & $\begin{array}{l}\text { OR }(95 \% \mathrm{Cl}) \mathrm{P}- \\
\text { value }\end{array}$ \\
\hline & 18 & 33 & Reference & 41 & 10 & Reference \\
\hline ID(53) & 16 & 37 & $\begin{array}{l}0.79(0.34-1.80) \\
0.675\end{array}$ & 26 & 27 & $\begin{array}{l}0.23(0.09-0.56) \\
0.001\end{array}$ \\
\hline $\mathrm{DD}(23)$ & 07 & 16 & $\begin{array}{l}0.80(0.27-2.31) \\
0.792\end{array}$ & 16 & 07 & $\begin{array}{l}0.55(0.18-1.72) \\
0.373\end{array}$ \\
\hline I allele & 52 & 100 & Reference & 108 & 47 & Reference \\
\hline $\begin{array}{l}\mathrm{D} \\
\text { allele }\end{array}$ & 30 & 68 & $\begin{array}{l}0.85(0.49-1.46) \\
0.583\end{array}$ & 58 & 41 & $\begin{array}{l}0.61(0.36-1.04) \\
0.079\end{array}$ \\
\hline
\end{tabular}

Since these two polymorphisms have been reported to be in linkage disequilibrium, a combined genotypic distribution was carried out where IIGG was observed with highest frequency of $25.2 \%$, followed by IDGG (22.8\%), IDAA (18.7\%), IIAA (16.3\%), DDGG (10.6\%), DDAA (5.7\%) and DDGA (0.8\%). The analysis was carried out between hospitalized and non hospitalized covid-19 subjects and those with and without symptoms. No statistical significance was observed with any of the combined genotypes; although IIGG 
combined genotype showed an odds ratio of 3.50 and was prevalent in symptomatic covid- 19 subjects (Table 6).

Table 6

Analysis of ACE ID/ACE2 G8790A combined genotypes on the basis of severity and symptoms of covid19 infection

\begin{tabular}{|c|c|c|c|c|c|c|}
\hline \multirow[t]{2}{*}{ ID/G8790A } & \multicolumn{3}{|c|}{ Severity } & \multicolumn{3}{|c|}{ Symptoms } \\
\hline & $\begin{array}{l}\mathrm{HR}(\mathrm{n}= \\
41)\end{array}$ & $\begin{array}{l}\mathrm{HNR}(\mathrm{n}= \\
86)\end{array}$ & $\begin{array}{l}\text { OR }(95 \% \mathrm{Cl}), \mathrm{P}- \\
\text { value }\end{array}$ & $\begin{array}{l}\text { Yes }(n= \\
83)\end{array}$ & $\begin{array}{l}\text { No }(n= \\
44)\end{array}$ & $\begin{array}{l}\text { OR }(95 \% \mathrm{Cl}), \mathrm{P}- \\
\text { value }\end{array}$ \\
\hline IIAA (20) & 06 & 14 & Reference & 13 & 07 & Reference \\
\hline DDAA (07) & 01 & 06 & $\begin{array}{l}0.39(0.03-3.97) \\
0.633\end{array}$ & 05 & 02 & $\begin{array}{l}1.34(0.20-8.82) \\
1.000\end{array}$ \\
\hline DDGA (01) & 00 & 01 & - & 00 & 01 & - \\
\hline DDGG (13) & 05 & 08 & $\begin{array}{l}1.46(0.33-6.35) \\
0.713\end{array}$ & 09 & 04 & $\begin{array}{l}1.21(0.27-5.39) \\
1.000\end{array}$ \\
\hline IDAA (23) & 07 & 16 & $\begin{array}{l}1.02(0.27-3.76) \\
1.000\end{array}$ & 14 & 09 & $\begin{array}{l}0.83(0.24-2.90) \\
1.000\end{array}$ \\
\hline IDGG (28) & 09 & 19 & $\begin{array}{l}1.10(0.31-3.83) \text {, } \\
1.000\end{array}$ & 17 & 11 & $\begin{array}{l}0.83(0.25-2.74) \\
1.000\end{array}$ \\
\hline IIGG (30) & 12 & 18 & $\begin{array}{l}1.56(0.46-5.18) \\
0.555\end{array}$ & 26 & 04 & $\begin{array}{l}3.50(0.86- \\
14.16), 0.09\end{array}$ \\
\hline
\end{tabular}

Mean IgG level and mean resolution-time was calculated in covid-19 subjects carrying G8790A wild (GG) and variant (AA) genotypes and their non-parametric $t$-test revealed no significance. Comparison of ACE I/D genotypes with IgG levels and resolution-time also revealed no statistical significance (Table 7).

Table 7

Comparison of ACE G8790A and ACEI/D with IgG levels and resolution-time

\begin{tabular}{|lllll|}
\hline G8790A & IgG levels & P-value & Resolution-time & P-value \\
\hline GG (70) & $10.67 \pm 14.20$ & 0.11 & $12.73 \pm 4.91$ & 0.97 \\
\hline AA (56) & $7.16 \pm 9.25$ & & $12.70 \pm 5.38$ & \\
ACE I/D & & & & \\
II(51) & $7.92 \pm 11.08$ & - & $12.24 \pm 5.18$ & - \\
\hline ID(53) & $10.79 \pm 14.11$ & 0.252 & $13.32 \pm 5.16$ & 0.289 \\
\hline DD(23) & $8.31 \pm 10.54$ & 0.887 & $11.77 \pm 4.17$ & 0.703 \\
\hline
\end{tabular}




\section{Discussion}

The pathological mechanisms involved in the interaction of SARS-CoV-2 are of key significance for infection and viral replication. Whilst a well-regulated immune response is essential in controlling SARSCoV-2 infection, the ability of this virus to disrupt the normal immune responses leads to an uncontrolled immune modulation. In this study, we hypothesized that SARS-CoV-2 IgG level, ACE2 G8790A and ACE I/D polymorphism may impact the SARS-CoV-2 infection and its outcomes. We observed a significant association of SARS-CoV-2 IgG levels with smoking history, dwelling and age, with comparatively higher levels in non smokers, urban and those aged above 35 years. An interesting observation was that SARSCoV-2 IgG levels were comparatively higher in subjects who had conspicuous complications coupled with need for hospitalization suggesting that SARS-CoV-2 IgG levels might be helpful in evaluating the course of disease and predicting the prognosis as also suggested by Wu et al., 2019 [26]. Correlation analysis of SARS-CoV-2 IgG levels with the resolution-time revealed insignificant statistical results. However, resolution-time as a dependent variable showed significant association with age and H1N1 vaccination. Subjects aged more than 35 years showed a mean resolution-time of 13.76 which was significantly higher than younger sub group $(P<0.05)$. In addition, subjects who had vaccinated themselves against H1N1 presented with a lower resolution-time $(p<0.05)$ suggesting that previous vaccination against H1N1 may cross protect against SARS-CoV-2 infection. Several studies have evaluated immune responses in $\mathrm{H} 1 \mathrm{~N} 1$ and SARS-CoV-2 co-infected models and have revealed some important considerations. Zhang et al., revealed that simultaneous or sequential co-infection by SARS-CoV-2 and H1N1 caused more severe disease than infection by either virus in hamsters although prior H1N1 infection lowered SARS-CoV-2 pulmonary viral load [27]. In an experimental model, Bao et al., reported that co-vaccination effectively protected K18-hACE2 mice against both H1N1 and SARS-CoV-2 infection [28]. A case report from an Influenza-like illness surveillance site in Egypt reported rapid resolution of SARS-CoV-2 and H1N1 co-infection in a 21-year-old woman and her family without treatment [29]. Thus, exploring the cross-protective role of neutralizing antibodies combined with co-vaccination strategies may hold promise against different variants of SARS virus as also suggested by persistence of lower resolution-time in $\mathrm{H} 1 \mathrm{~N} 1$ vaccinated subgroup in our study and may be an effective tool in developing more efficacious vaccines to support and succor the management of covid-19 pandemic.

\section{Role of ACE2 G8790A and ACE ID Polymorphisms in SARS-CoV-2}

SARS-Cov-2 infection is mediated by its binding with ACE2 receptor, a membrane exopeptidase, present on the host cells. Apparently, it seems concurring that the extent of ACE2 expression may determine the severity of this infection. Various studies have correlated ACE2 expression and its polymorphisms with covid-19 severity and most importantly ACE2 is overexpressed in men suggesting a higher sensitivity against the adverse effects of covid-19 infection [30,31]. Various studies have investigated the potential for ACE2 polymorphisms to explain population-based differences in Covid-19 severity [30,32]. In current study, frequency of G8790A GG genotype was observed to be considerably higher in subjects who required hospitalization suggesting $G G$ genotype to be a potential genetic risk which could be predicative of disease severity. Carriers of G8790A GG genotype had higher anti covid-19 IgG titers as compared to 
those who carried AA genotype; however the results were statistically insignificant. In addition, no significant difference in the resolution-time of covid-19 infection was observed between the carriers of GG and AA genotypes. G8790A is located at the beginning of intron 2 and may play a possible role in splicing process which may in turn alter the expression level of ACE $2[20,33]$. AA genotype has been observed to be associated with higher expression of ACE2. A study reported A/A genotype to increase the expression level of ACE2 by almost $50 \%$ in comparison to the $G / G$ genotype [22]. This variant has been extensively studied as a potential risk factor for hypertension, type-2 diabetes, and coronary artery disease $[22,23$, 34]. Contrary to these reports, a study carried out in Indian sub continent showed a strong association of G8790A ' $A$ ' allele with lower infection rate and lower CFR thus highlighting its protective role which holds true for the current study as we observed an odds ratio of 0.4 associated with this genotype which was statistically significant $(O R=0.40(0.141-0.717), P=0.007)$ [16]. The $G G$ form of rs2285666 binds to heterogeneous ribonucleoprotein D-like (hnRNPDL) which is an RNA-processing prion-like protein with three alternative splicing (AS) isoforms, which lack none, one, or both of its two disordered domains. It has been suggested that alternative splicing might regulate the assembly properties of RNA-processing proteins by controlling the incorporation of multivalent disordered regions in the isoforms which would modulate their activity in the downstream splicing program [35]. Pouladi et al., demonstrated that binding of hnRNP DL to the GG form of rs2285666 enhances the splicing and produce an ACE2 with more binding affinity to the SARS-CoV-2, which may increase susceptibility to infection and aggravation of related complications [36]. The other variant which was genotyped in this study was $A C E$ I/D, where ID genotype was observed to show protective role in comparison to II genotype. DD genotype and $D$ allele although showed an OR of 0.56 and 0.65 respectively in comparison to II genotype, the results were statistically insignificant. There is evidence that ACE I/D genotypes affect the outcomes of acute respiratory distress syndrome (ARDS) treatment which is one of the aggressive outcomes of Covid-19 infection [37, 38]. Adamzik et al reported ACE DD genotype to be associated with increased mortality in Caucasian population [39]. Matteo Bellone et al associated ACE DD genotype with increased serum ACE levels and proposed that ACE DD variant might be predictive of more aggressive outcomes of covid-19 infection [40]. Various other population based studies have demonstrated that COVID-19 may be associated with ACE I/D polymorphism, with increasing $D$ allele frequency correlating to a reduction in prevalence but increase in mortality from COVID-19 infection [41-43]. Currently, it remains unclear whether ACE polymorphisms are associated with the observed variations in COVID-19 mortality among different ethnicities and to what extent does the frequency of the II and DD genotypes contribute to the covid-19 severity. This study surmises that ACE ID genotype (heterozygous) bears protective role against covid-19 which supports the notion that $D$ allele favors reduced prevalence of covid-19. The apparent inconstancy may be because of different ethnicity, and the fact that this study was carried out in covid-19 recovered patients offsets the possibility to observe reported association of ACEI/D DD variant with increased mortality. Based on the close proximity of ACE2 G8790A and ACE ID; these polymorphisms being in linkage disequilibrium, we further carried out their combined genotypic distribution, however the results were statistically insignificant. 
In conclusion the aforementioned results suggest that ACE G8790A GG genotype carries a significant risk for covid-19 severity whereas ACE I/D heterozygous genotype bears protective role. The study provides preliminary evidence of a genetic link between the mentioned variants and COVID-19 suggesting a subtle way of COVID-19 risk stratification and utilization of respective variants as predictive biomarkers. In addition, we report a significant association of anti SARS-CoV-2 IgG levels with covid-19 severity. At an individual level, risk stratification involving ACE I/D and ACE2 G8790A combined with status of SARSCoV-2 IgG titers might be helpful in evaluating the course of disease, predicting the prognosis and may be an effective tool in improving patient outcomes, management of covid-19 and related complications.

\section{Abbreviations}

SARS: Severe acute respiratory syndrome; Ig: Immunoglobulin; ACE: Angiotensin converting enzyme; PCR: Polymerase chain reaction; RFLP: Restriction fragment length polymorphism; CFR: Case fatality rate

\section{Declarations}

\section{Acknowledgement:}

The authors are thankful to 'Sher-i-Kashmir Institute of Medical Sciences, Kashmir, India' for supporting this research through grant number \# 448/2020. In addition, the authors would like to thank the technical staff of Department of immunology \& Molecular Medicine, SKIMS, Srinagar.

\section{References}

1. Velavan TP, Meyer CG (2020) The COVID-19 epidemic. Trop Med Int Health 25(3):278-280

2. Huang C, Wang Y, Li X, Ren L, Zhao J, Hu Y, Zhang L, Fan G, Xu J, Gu X et al (2020) Clinical features of patients infected with 2019 novel coronavirus in Wuhan, China. Lancet 395(10223):497-506

3. Konturek PC, Harsch IA, Neurath MF, Zopf Y: COVID-19 - more than respiratory disease: a gastroenterologist's perspective. J Physiol Pharmacol 2020, 71(2)

4. Guan WJ, Ni ZY, Hu Y, Liang WH, Ou CQ, He JX, Liu L, Shan H, Lei CL, Hui DSC et al (2020) Clinical Characteristics of Coronavirus Disease 2019 in China. N Engl J Med 382(18):1708-1720

5. Francone M, lafrate F, Masci GM, Coco S, Cilia F, Manganaro L, Panebianco V, Andreoli C, Colaiacomo MC, Zingaropoli MA et al (2020) Chest CT score in COVID-19 patients: correlation with disease severity and short-term prognosis. Eur Radiol 30(12):6808-6817

6. Adhikari SP, Meng S, Wu YJ, Mao YP, Ye RX, Wang QZ, Sun C, Sylvia S, Rozelle S, Raat H et al (2020) Epidemiology, causes, clinical manifestation and diagnosis, prevention and control of coronavirus disease (COVID-19) during the early outbreak period: a scoping review. Infect Dis Poverty 9(1):29

7. Volpicelli G, Gargani L (2020) Sonographic signs and patterns of COVID-19 pneumonia. Ultrasound J 12(1):22 
8. Fathi N, Rezaei N (2020) Lymphopenia in COVID-19: Therapeutic opportunities. Cell Biol Int 44(9):1792-1797

9. Velavan TP, Meyer CG (2020) Mild versus severe COVID-19: Laboratory markers. Int J Infect Dis 95:304-307

10. Borak J (2020) Airborne Transmission of COVID-19. Occup Med (Lond) 70(5):297-299

11. WH. O: Modes of transmission of virus causing COVID-19: implications for IPC precaution recommendations. 2020.

12. Cai J, Sun W, Huang J, Gamber M, Wu J, He G (2020) Indirect Virus Transmission in Cluster of COVID19 Cases, Wenzhou, China, 2020. Emerg Infect Dis 26(6):1343-1345

13. Karia R, Gupta I, Khandait H, Yadav A, Yadav A: COVID-19 and its Modes of Transmission. SN Compr Clin Med 2020:1-4

14. Organization WH: Weekly epidemiological update on covid. 2021

15. Hamming I, Timens W, Bulthuis ML, Lely AT, Navis G, van Goor H (2004) Tissue distribution of ACE2 protein, the functional receptor for SARS coronavirus. A first step in understanding SARS pathogenesis. J Pathol 203(2):631-637

16. Srivastava A, Bandopadhyay A, Das D, Pandey RK, Singh V, Khanam N, Srivastava N, Singh PP, Dubey PK, Pathak A et al (2020) Genetic Association of ACE2 rs2285666 Polymorphism With COVID-19 Spatial Distribution in India. Front Genet 11:564741

17. Asselta R, Paraboschi EM, Mantovani A, Duga S (2020) ACE2 and TMPRSS2 variants and expression as candidates to sex and country differences in COVID-19 severity in Italy. Aging 12(11):1008710098

18. Hubacek JA, Dusek L, Majek O, Adamek V, Cervinkova T, Dlouha D, Adamkova V (2021) ACE I/D polymorphism in Czech first-wave SARS-CoV-2-positive survivors. Clin Chim Acta 519:206-209

19. Gard PR (2010) Implications of the angiotensin converting enzyme gene insertion/deletion polymorphism in health and disease: a snapshot review. Int J Mol Epidemiol Genet 1(2):145-157

20. Pinheiro DS, Santos RS, Jardim P, Silva EG, Reis AAS, Pedrino GR, Ulhoa CJ (2019) The combination of ACE I/D and ACE2 G8790A polymorphisms revels susceptibility to hypertension: A genetic association study in Brazilian patients. PLoS One 14(8):e0221248

21. Sarangarajan R, Winn R, Kiebish MA, Bountra C, Granger E, Narain NR: Ethnic Prevalence of Angiotensin-Converting Enzyme Deletion (D) Polymorphism and COVID-19 Risk: Rationale for Use of Angiotensin-Converting Enzyme Inhibitors/Angiotensin Receptor Blockers. $J$ Racial Ethn Health Disparities 2020

22. Wu YH, Li JY, Wang C, Zhang LM, Qiao H: The ACE2 G8790A Polymorphism: Involvement in Type 2 Diabetes Mellitus Combined with Cerebral Stroke. J Clin Lab Anal 2017, 31(2)

23. Liu C, Li Y, Guan T, Lai Y, Shen Y, Zeyaweiding A, Zhao H, Li F, Maimaiti T (2018) ACE2 polymorphisms associated with cardiovascular risk in Uygurs with type 2 diabetes mellitus. Cardiovasc Diabetol 17(1):127 
24. Behl T, Kaur I, Bungau S, Kumar A, Uddin MS, Kumar C, Pal G, Sahil, Shrivastava K, Zengin G et al (2020) The dual impact of ACE2 in COVID-19 and ironical actions in geriatrics and pediatrics with possible therapeutic solutions. Life Sci 257:118075

25. Sienko J, Kotowski M, Bogacz A, Lechowicz K, Drozdzal S, Rosik J, Sietnicki M, Sienko M, Kotfis K (2020) COVID-19: The Influence of ACE Genotype and ACE-I and ARBs on the Course of SARS-CoV-2 Infection in Elderly Patients. Clin Interv Aging 15:1231-1240

26. Wu LX, Wang H, Gou D, Fu G, Wang J, Guo BQ (2021) Clinical significance of the serum IgM and IgG to SARS-CoV-2 in coronavirus disease-2019. J Clin Lab Anal 35(1):e23649

27. Zhang AJ, Lee AC, Chan JF, Liu F, Li C, Chen Y, Chu H, Lau SY, Wang P, Chan CC et al (2021) Coinfection by Severe Acute Respiratory Syndrome Coronavirus 2 and Influenza A(H1N1)pdm09 Virus Enhances the Severity of Pneumonia in Golden Syrian Hamsters. Clin Infect Dis 72(12):e978e992

28. Bao L, Deng W, Qi F, Lv Q, Song Z, Liu J, Gao H, Wei Q, Yu P, Xu Y et al (2021) Sequential infection with H1N1 and SARS-CoV-2 aggravated COVID-19 pathogenesis in a mammalian model, and covaccination as an effective method of prevention of COVID-19 and influenza. Signal Transduct Target Ther 6(1):200

29. Fahim M, Ghonim H, Roshdy WH, Naguib A, Elguindy N, AbdelFatah M, Hassany M, Mohsen A, Afifi S, Eid A (2021) Coinfection With SARS-CoV-2 and Influenza A(H1N1) in a Patient Seen at an Influenzalike Illness Surveillance Site in Egypt: Case Report. JMIR Public Health Surveill 7(4):e27433

30. Devaux CA, Rolain JM, Raoult D (2020) ACE2 receptor polymorphism: Susceptibility to SARS-CoV-2, hypertension, multi-organ failure, and COVID-19 disease outcome. J Microbiol Immunol Infect 53(3):425-435

31. Beyerstedt S, Casaro EB, Rangel EB (2021) COVID-19: angiotensin-converting enzyme 2 (ACE2) expression and tissue susceptibility to SARS-CoV-2 infection. Eur J Clin Microbiol Infect Dis 40(5):905-919

32. Hou Y, Zhao J, Martin W, Kallianpur A, Chung MK, Jehi L, Sharifi N, Erzurum S, Eng C, Cheng F (2020) New insights into genetic susceptibility of COVID-19: an ACE2 and TMPRSS2 polymorphism analysis. BMC Med 18(1):216

33. Patel SK, Velkoska E, Freeman M, Wai B, Lancefield TF, Burrell LM (2014) From gene to proteinexperimental and clinical studies of ACE2 in blood pressure control and arterial hypertension. Front Physiol 5:227

34. Lu N, Yang Y, Wang Y, Liu Y, Fu G, Chen D, Dai H, Fan X, Hui R, Zheng Y (2012) ACE2 gene polymorphism and essential hypertension: an updated meta-analysis involving 11,051 subjects. Mol Biol Rep 39(6):6581-6589

35. Batlle C, Yang P, Coughlin M, Messing J, Pesarrodona M, Szulc E, Salvatella X, Kim HJ, Taylor JP, Ventura S (2020) hnRNPDL Phase Separation Is Regulated by Alternative Splicing and DiseaseCausing Mutations Accelerate Its Aggregation. Cell Rep 30(4):1117-1128 e1115 
36. Pouladi N, Abdolahi S: Investigating the ACE2 polymorphisms in COVID-19 susceptibility: An in silico analysis. Mol Genet Genomic Med 2021:e1672

37. Tsantes AE, Kopterides P, Bonovas S, Bagos P, Antonakos G, Nikolopoulos GK, Gialeraki A, Kapsimali V, Kyriakou E, Kokori S et al (2013) Effect of angiotensin converting enzyme gene I/D polymorphism and its expression on clinical outcome in acute respiratory distress syndrome. Minerva Anestesiol 79(8):861-870

38. Marshall RP, Webb S, Bellingan GJ, Montgomery HE, Chaudhari B, McAnulty RJ, Humphries SE, Hill MR, Laurent GJ (2002) Angiotensin converting enzyme insertion/deletion polymorphism is associated with susceptibility and outcome in acute respiratory distress syndrome. Am J Respir Crit Care Med 166(5):646-650

39. Adamzik M, Frey U, Sixt S, Knemeyer L, Beiderlinden M, Peters J, Siffert W (2007) ACE I/D but not AGT (-6)A/G polymorphism is a risk factor for mortality in ARDS. Eur Respir J 29(3):482-488

40. Bellone M, Calvisi SL (2020) ACE polymorphisms and COVID-19-related mortality in Europe. J Mol Med (Berl) 98(11):1505-1509

41. Delanghe JR, Speeckaert MM, De Buyzere ML (2020) COVID-19 infections are also affected by human ACE1 D/I polymorphism. Clin Chem Lab Med 58(7):1125-1126

42. Delanghe JR, Speeckaert MM, De Buyzere ML (2020) The host's angiotensin-converting enzyme polymorphism may explain epidemiological findings in COVID-19 infections. Clin Chim Acta 505:192-193

43. Aung AK, Aitken T, Teh BM, Yu C, Ofori-Asenso R, Chin KL, Liew D (2020) Angiotensin converting enzyme genotypes and mortality from COVID-19: An ecological study. J Infect 81(6):961-965

\section{Figures}




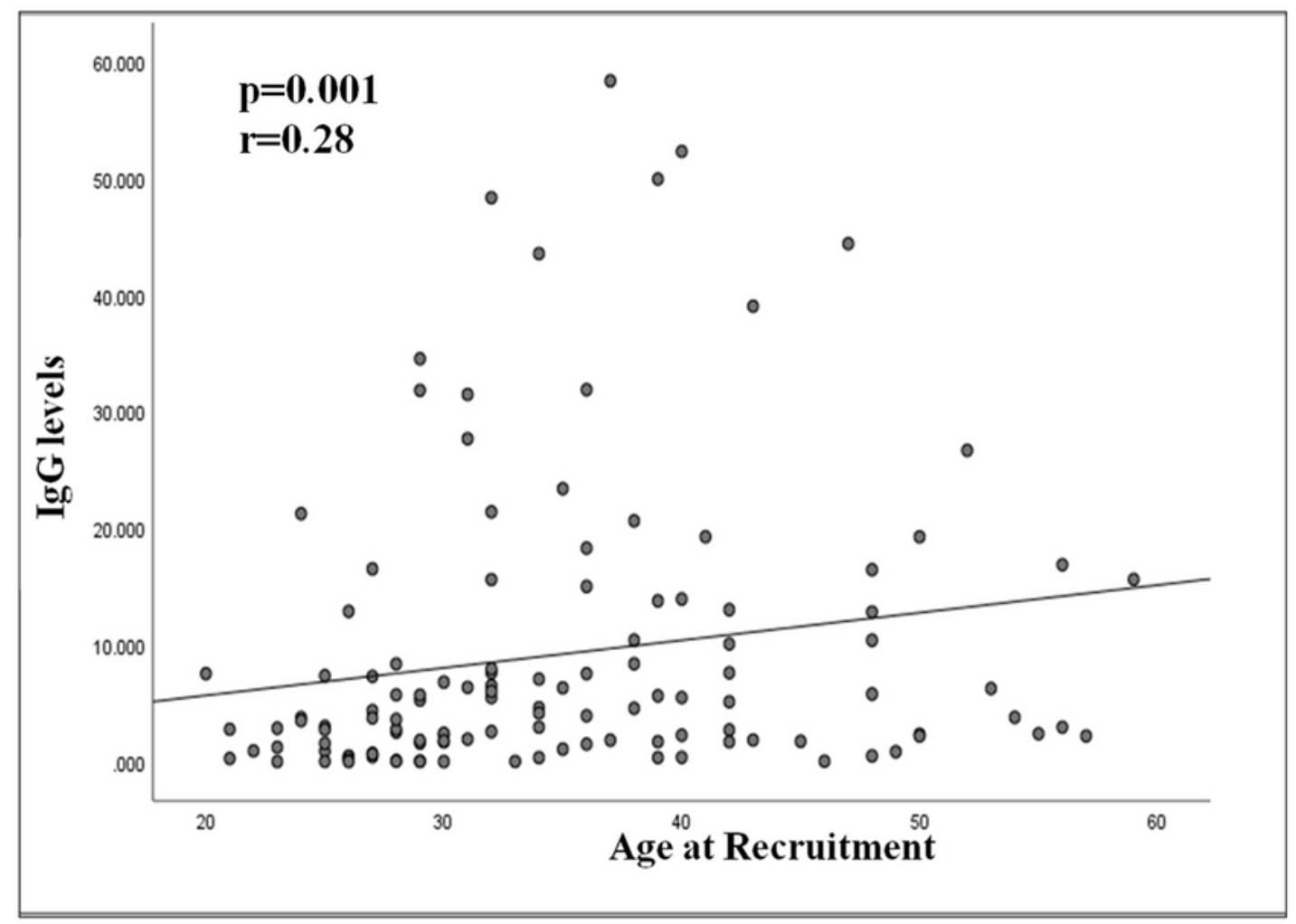

Figure 1

Correlation analysis between anti SARS-CoV-2 lgG levels and age at recruitment 


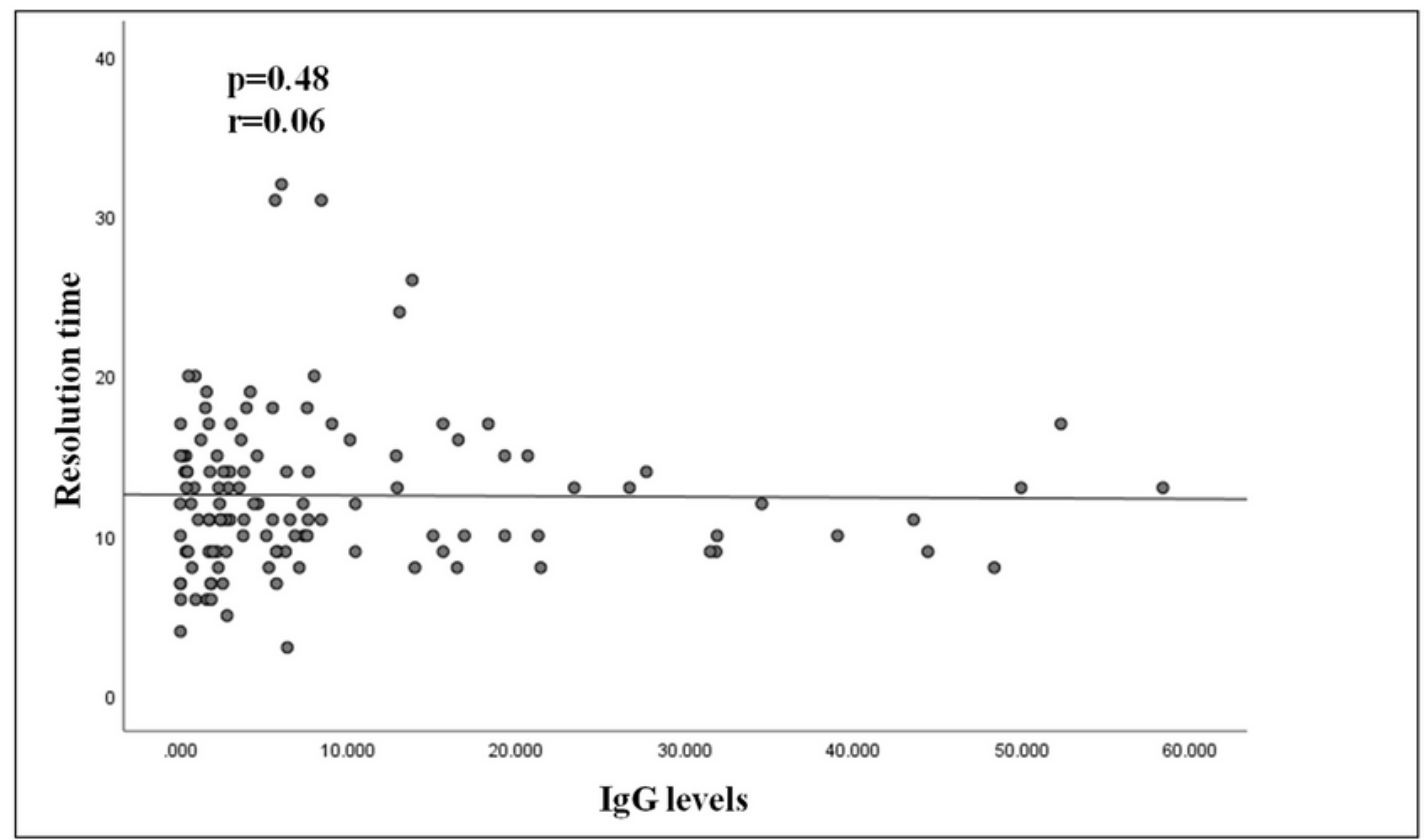

Figure 2

Correlation analysis between anti SARS-CoV-2 IgG levels and resolution-time 


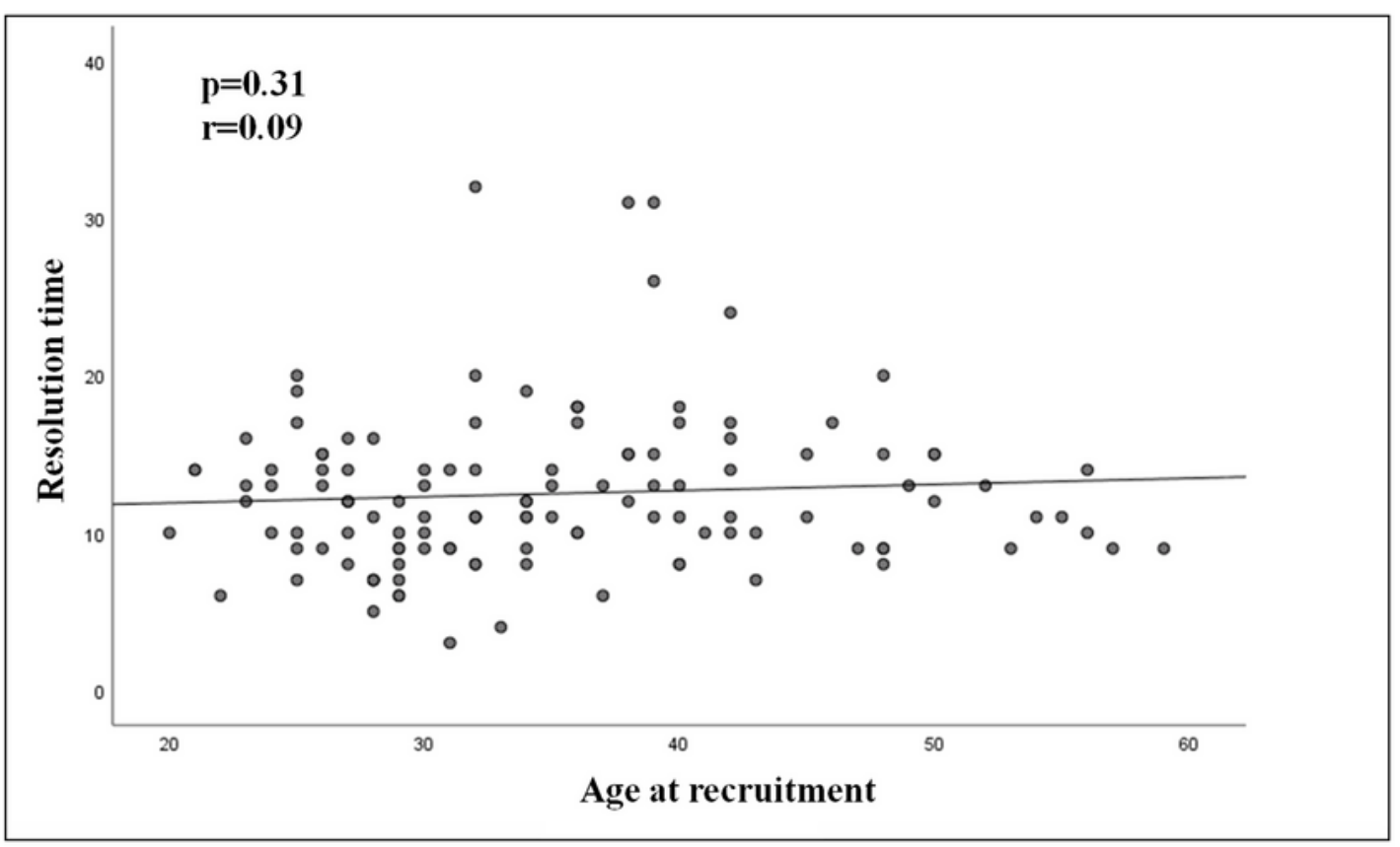

Figure 3

Correlation analysis between resolution-time and age at recruitment 